\title{
Early induction versus expectant management in prelabour rupture of membranes
}

\author{
Anjali Gupta, Sarika Gautam*, Om Prakash, Meenakshi Chauhan
}

Department of Obstetrics and Gynecology, Pt B D Sharma PGIMS, Rohtak, Haryana, India

Received: 2 September July 2018

Accepted: 28 September 2018

*Correspondence:

Dr. Sarika Gautam,

E-mail: sarika.gautam07@gmail.com

Copyright: ( ) the author(s), publisher and licensee Medip Academy. This is an open-access article distributed under the terms of the Creative Commons Attribution Non-Commercial License, which permits unrestricted non-commercial use, distribution, and reproduction in any medium, provided the original work is properly cited.

\begin{abstract}
Background: Prelabour rupture of membrane defined as spontaneous rupture of membrane prior to the onset of regular uterine contractions. The incidence of PROM varies from 6-18\%. Management of term PROM is not having specific guidelines leading to management dilemma.

Methods: This prospective study was conducted on 100 women with singleton pregnancy, cephalic presentation with spontaneous PROM at term. The aim to compare maternal and perinatal outcome of early induction with expectant management in women with PROM. The patients were divided into two group expectant group and early induction group. Induction of labour was done by PGE2 gel and expectant group patient were observed for 24 hours for spontaneous labour since leaking. Augmentation of labour was done with Oxytocin if required. Outcomes were measured as PROM to delivery interval, induction to delivery interval, mode of delivery, maternal and neonatal morbidity.

Results: Eighty percent of women of expectant group went into active labour within 24 hours, and all patient of induction group went into active labour in 18 hours $(\mathrm{p}<0.001)$. ROM to active labour interval and ROM to delivery interval were significantly less in early induction group, (9.87 and 17.212 hour) compared to expectant group (19.118 and 23.34-hour, $\mathrm{p}<0.001)$. Fetal distress and LSCS were comparatively higher in induction group (16\%vs $2 \%$ $\mathrm{p}=0.038$ ). Neonatal Sepsis was seen more in expectant group but statistically insignificant ( $22 \%$ versus $16 \%, \mathrm{p}=0.26)$. Conclusions: Women with term PROM can be given informed choice of expectant management and early induction explaining the merits and demerits of both options.
\end{abstract}

Keywords: Induction of Labour, Neonatal sepsis, Oxytocin, Prelabour rupture of membranes, PGE2 Gel

\section{INTRODUCTION}

Prelabour rupture of membranes (PROM) is one of the most common clinical problem where a low risk pregnancy can turn into high risk pregnancy at term. Prelabour rupture of membranes is defined by the American college of Obstetrics and gynaecology as "Spontaneous rupture of membranes prior to the onset of regular uterine contractions." 1 PROM occurs in 6-18\% of all pregnancies of which $80 \%$ occurs at term. ${ }^{2}$

Exact etiology of PROM is not known, PROM at term is known to be associated with either increased intra uterine pressure due to multiple pregnancy, polyhydramnios or due to weakening of membranes.

Weakening of membranes could be either congenital or acquired (smoking, vitamins deficit) or because of damaging factors either mechanical or chemical like frequent digital examination, coitus, and infections (trichomonas, Group B streptococcus, bacterial vaginosis). ${ }^{3}$

It could be diagnosed by direct methods as well as indirect methods. Direct method includes observation of pooled amniotic fluid deep in vagina with the help of 
speculum, indirect methods include assessment of ferning of sample collected from posterior fornix under the microscope or testing of $\mathrm{pH}$ of similarly collected sample by Nitrazine Paper4. PROM results in $40 \%$ of preterm birth and contributes in perinatal mortality by $10 \% .^{5}$ Spontaneous labour starts in 12 hours of PROM, within $24 \mathrm{hrs}$ in $86 \%$ of cases, and within 96 hours in 4 to $8 \%$ of cases while $6 \%$ will not go in labour even after 96 hours. ${ }^{3}$

It results in various complications some immediate while some late like cord compressions leading to fetal distress, cord prolapse and stillbirth, abruption, increased operative interference, fetal and maternal infections including Chorioamnionitis. ${ }^{6}$ The management of PROM at term is matter up for discussion for expectant management vs induction of labour. Now a day's many obstetricians are in favour of induction in view of ascending infection. On contrary other authors argue even expectant management doesn't correlate with rate of caesarean section and infection. The management of PROM still remains a dilemma, so the present study is aimed to compare the maternal and perinatal outcome of early induction versus expectant management in women with PROM at term gestation.

\section{METHODS}

A prospective study was conducted on 100 women with singleton pregnancy, cephalic presentation with spontaneous Prelabour rupture of membranes between 37 to 41 completed weeks admitted to labour room of Department of Obstetrics and Gynaecology, Pt B.D. Sharma PGIMS, Rohtak. Pregnancy with scarred uterus, multiple pregnancy, abruption placenta, IUGR, PPROM ( $<37$ week), features of chorioamnionitis, and medical or obstetrical disorders which need to expedite the delivery were excluded. The study patients were allocated in two groups $\mathrm{A}$ and $\mathrm{B}$ by computer generated randomization. Group A patient were kept on expectant management while group B patient were induced after 6 hours of PROM. All patients received injection Ampicillin 500 mg 6 hourly till delivery.

Expectancy time allotted to group A patient was 24 hours for spontaneous labour. Induction of labour was done by intracervical PGE2 gel maximum of two doses 6 hours apart or by oxytocin depending on the Bishop's score. Augmentation of labour was also done if needed. Partogram was plotted to assess progress of labour in both the groups. Cases were considered of failed induction and subjected to caesarean section if they didn't go into labour after 2 doses of PGE2 gel and Bishop Score is $<8$. Antibiotics were given to all neonates with sepsis and prophylactically who delivered after 24 hours of PROM.

Primary outcome was measured as rupture of membranes to delivery interval, mode of delivery maternal and neonatal morbidity. Secondary outcome was measured in terms of dose and duration of PGE2/ oxytocin used for induction. Data was statistically analysed by using chisquare test, paired-t test. $\mathrm{P}$ value $<0.5$ was considered as significant.

\section{RESULTS}

In the present study maximum patients were of 20 to 30 years as shown in Table 1.

Table 1 Description of the patients.

\begin{tabular}{|c|c|c|c|c|c|}
\hline & \multicolumn{2}{|c|}{$\begin{array}{l}\text { Group A } \\
\text { (expectant } \\
\text { group) } \mathbf{n}=\mathbf{5 0} \%\end{array}$} & \multicolumn{2}{|c|}{$\begin{array}{l}\text { Group B } \\
\text { (induction } \\
\text { group) } n=50 \%\end{array}$} & $\begin{array}{l}p \\
\text { value }\end{array}$ \\
\hline \multicolumn{6}{|c|}{ Age (years) } \\
\hline$<19$ & 1 & 2 & 0 & 0 & - \\
\hline $20-24$ & 29 & 58 & 29 & 58 & 0.674 \\
\hline $25-29$ & 15 & 30 & 17 & 34 & 0.705 \\
\hline$\geq 30$ & 5 & 10 & 4 & 8 & 0.600 \\
\hline Mean \pm SD & \multicolumn{2}{|c|}{$23.94 \pm 2.90$} & \multicolumn{2}{|c|}{$24.34 \pm 3.07$} & 0.349 \\
\hline \multicolumn{6}{|l|}{ Parity } \\
\hline P0 & 29 & 58 & 27 & 54 & 0.634 \\
\hline $\mathrm{P} 1$ & 13 & 26 & 15 & 30 & 0.326 \\
\hline $\mathrm{P} 2$ & 4 & 8 & 5 & 10 & 0.712 \\
\hline P3 & 3 & 6 & 2 & 4 & 0.690 \\
\hline P4 & 1 & 2 & 0 & 0 & - \\
\hline$>\mathrm{P} 4$ & 0 & 0 & 1 & 2 & - \\
\hline \multicolumn{6}{|c|}{ Gestational age } \\
\hline $37-38$ & 20 & 40 & 13 & 26 & \\
\hline $38-39$ & 13 & 26 & 19 & 38 & \\
\hline $39-40$ & 10 & 20 & 12 & 24 & \\
\hline $40-41$ & 7 & 14 & 6 & 12 & \\
\hline Mean \pm SD & \multicolumn{2}{|c|}{$38.68 \pm 1.34$} & \multicolumn{2}{|c|}{$38.62 \pm 1.58$} & 0.332 \\
\hline \multicolumn{6}{|c|}{ Booking status } \\
\hline Booked & 21 & 42 & 19 & 38 & \\
\hline Unbooked & 29 & 58 & 32 & 62 & 0.724 \\
\hline
\end{tabular}

Table 2: Status of the patient at the time of admission.

\begin{tabular}{|c|c|c|c|}
\hline $\begin{array}{l}\text { Duration of } \\
\text { ruptured } \\
\text { membranes } \\
\text { (hours) }\end{array}$ & $\begin{array}{l}\text { Group A } \\
\text { (expectant } \\
\text { group) } \\
\mathrm{n}=50 \%\end{array}$ & $\begin{array}{l}\text { Group B } \\
\text { (induction } \\
\text { group) } \\
\text { n }=50 \%\end{array}$ & P value \\
\hline$<2$ & 12 & 48 & \\
\hline $2-4$ & 20 & 4 & \\
\hline $4-6$ & 39 & 84 & \\
\hline Mean \pm SD & $5.64 \pm 0.846$ & $5.03 \pm 1.539$ & 0.617 \\
\hline \multicolumn{4}{|c|}{ Bishop's score } \\
\hline $0-1$ & 4 & 4 & \\
\hline $2-3$ & 44 & 20 & \\
\hline $4-5$ & 48 & 26 & \\
\hline Mean \pm SD & $3.468 \pm 1.01$ & $3.342 \pm 1.09$ & 0.387 \\
\hline
\end{tabular}

The mean age is $23.94 \pm 2.90$ in Group A and 24.34 \pm 3.07 in group B and no statistical significance was found in both the groups $(p$ value $=0.349)$. Majority of the patients were nulliparous in both the groups. The mean gestational age were similar in both the groups and was statistically insignificant $(\mathrm{p}=0.332)$. The number of unbooked cases were seen higher than the booked cases 
in both the groups. At the time of admission patients were assessed for their basic details, duration of ruptured membranes and Bishops score at the time of induction or at established labour and comparable in both the groups as depicted in Table 2. Latency (PROM to active labour interval) was observed at every 6-hour interval (Table 3) and was significantly shorter in Group B as compared to Group A $(9.87 \pm 6.341$ and $19.118 \pm 10.465)$ with $p$ value
$<0.001$. All women achieved active labour in 18 hours in group B whereas only $50 \%$ achieved it in group A. six women didn't go in labour in group A even after 24 hours and were induced. PROM to delivery interval was observed and it was significant also lesser in group B (17.212 \pm 5.388 hours) as compared to Group A (23.23 \pm $6.804)$ with $\mathrm{p}$ value of $<0.001$.

Table 3: Latency period and PROM to delivery interval.

\begin{tabular}{|c|c|c|c|c|c|}
\hline \multirow{2}{*}{$\begin{array}{l}\text { Rupture of membrane to active labour } \\
\text { interval (hours) }\end{array}$} & \multicolumn{2}{|c|}{ Group A (expectant group) } & \multicolumn{2}{|c|}{ Group B (induction group) } & \multirow{2}{*}{$P$ value } \\
\hline & $\mathrm{n}=\mathbf{5 0}$ & $\%$ & $\mathrm{n}=\mathbf{5 0}$ & $\%$ & \\
\hline$\leq 6$ & 0 & 0 & 0 & 0 & - \\
\hline$\leq 12$ & 9 & 18 & 29 & 58 & $<0.001$ \\
\hline$\leq 18$ & 25 & 50 & 50 & 100 & $<0.001$ \\
\hline$\leq 24$ & 44 & 88 & - & & \\
\hline$\leq 30$ & 48 & 96 & - & & \\
\hline$>30$ & 50 & 100 & - & & \\
\hline Mean \pm SD & $19.118 \pm 10.465$ & & $9.87 \pm 6.341$ & & $<0.001$ \\
\hline \multicolumn{6}{|l|}{ ROM to delivery interval } \\
\hline Within 12 hours & 2 & 4 & 9 & 18 & 0.076 \\
\hline Within 18 hours & 17 & 34 & 31 & 62 & $<0.001$ \\
\hline Within 24 hours & 19 & 38 & 43 & 86 & $<0.001$ \\
\hline Within 30 hours & 44 & 88 & 48 & 96 & 0.467 \\
\hline Within 36 hours & 46 & 92 & 49 & 98 & 0.811 \\
\hline Within 42 hours & 50 & 100 & 50 & 100 & 1 \\
\hline Mean \pm SD & $23.234 \pm 6.804$ & & $17.212 \pm 5.388$ & & $<0.001$ \\
\hline
\end{tabular}

Table 4: Induction of labour and its outcome.

\begin{tabular}{|c|c|c|c|c|c|}
\hline & \multicolumn{2}{|c|}{ Group A (expectant group) } & \multicolumn{2}{|c|}{ Group B (induction group) } & \multirow{2}{*}{ P value } \\
\hline & $\mathbf{n}=\mathbf{5 0}$ & $\%$ & $\mathbf{n}=\mathbf{5 0}$ & $\%$ & \\
\hline PGE2 once & 4 & 8 & 29 & 58 & \\
\hline Repeat PGE2 & 2 & 4 & 21 & 42 & \\
\hline Not induced & 44 & 88 & - & - & \\
\hline Mean \pm SD & $0.163 \pm 0.472$ & & $1.42 \pm 0.498$ & & $<0.001$ \\
\hline \multicolumn{6}{|l|}{ Oxytocin augmentation } \\
\hline Required & 18 & 36 & 16 & 32 & \\
\hline Not Required & 32 & 64 & 34 & 68 & 0.618 \\
\hline Induction to delivery interval & $\mathrm{n}=6^{*}$ & $\%$ & $\mathrm{n}=42^{* *}$ & $\%$ & \\
\hline$<12$ Hour & 4 & 67 & 19 & 45 & 0.001 \\
\hline 12-24 Hour & 2 & 33 & 13 & 31 & 0.865 \\
\hline$>24$ Hour & 0 & 0 & 10 & 24 & - \\
\hline Mean \pm SD & $10.825 \pm 2.232$ & & $12.912 \pm 5.388$ & & 0.013 \\
\hline Mode of delivery & $\mathbf{n}=\mathbf{5 0}$ & $\%$ & $\mathrm{n}=\mathbf{5 0}$ & $\%$ & \\
\hline Vaginal & 49 & 98 & 42 & 84 & \\
\hline LSCS & 1 & 2 & 8 & 16 & \\
\hline Failed induction & 0 & 0 & 0 & 0 & \\
\hline Fetal distress & 1 & 2 & 8 & 16 & 0.038 \\
\hline
\end{tabular}

*only 6 cases require induction in expectant group; **8 cases had LSCS before induction

Induction of labour and its outcome is shown in table 4 in group A only six patient required induction of labour after latency of 24 while in group B all 50 patient were induced after 6 hours (early induction) this was found statistically significant $(\mathrm{p}<0.001)$. Augmentation with oxytocin was required in group A $36 \%$ women while in 
group B, 32\% women require the augmentation of labour. It was statistically insignificant $(\mathrm{p}=0.618)$. In present study induction to delivery interval was less in group A as compared to group B $(\mathrm{p}=0.013)$. Ninety-eight $\%$ women delivered vaginally while $2 \%$ had Caesarean section with the indication of fetal distress. In group B $84 \%$ women had vaginal delivery while $16 \%$ undergo Caesarean section for fetal distress. The difference was found statistically significant $(\mathrm{p}=0.038)$. Failed induction was not observed in the present study.

Table 5: Neonatal outcome.

\begin{tabular}{|c|c|c|c|c|c|}
\hline \multirow[t]{2}{*}{ Neonatal outcome } & \multicolumn{2}{|c|}{ Group A (expectant Group) } & \multicolumn{2}{|c|}{ Group B (induction group) } & \multirow[t]{2}{*}{ P value } \\
\hline & $\mathbf{N}=\mathbf{5 0}$ & $\%$ & $\mathbf{N}=\mathbf{5 0}$ & $\%$ & \\
\hline \multicolumn{6}{|l|}{ Birth weight(kg) } \\
\hline$<1.5$ & 0 & 0 & 0 & 0 & 0.312 \\
\hline $1.5-2.4$ & 12 & 24 & 9 & 18 & 0.462 \\
\hline $2.5-3.0$ & 30 & 60 & 34 & 68 & 0.276 \\
\hline$>3.0$ & 8 & 16 & 7 & 14 & 0.662 \\
\hline Mean \pm SD & $2.69 \pm 0$ & & $2.63 \pm 0$ & & 0.662 \\
\hline \multicolumn{6}{|c|}{ APGAR Score at 1 minute } \\
\hline$<4$ & 0 & 0 & 0 & 0 & \multirow[b]{3}{*}{0.234} \\
\hline $4-6$ & 22 & 44 & 17 & 34 & \\
\hline$>7$ & 28 & 56 & 33 & 66 & \\
\hline \multicolumn{6}{|l|}{ At 5 minutes } \\
\hline$<4$ & 0 & 0 & 0 & 0 & \multirow{3}{*}{1.000} \\
\hline $4-6$ & 0 & 0 & 0 & 0 & \\
\hline$>7$ & 50 & 100 & 50 & 100 & \\
\hline Sepsis & 11 & 22 & 8 & 16 & 0.264 \\
\hline Jaundice & 6 & 12 & 1 & 2 & 0.054 \\
\hline Antibiotics & 21 & 42 & 15 & 30 & 0.044 \\
\hline Admission to NICU & 5 & 10 & 1 & 2 & 0.102 \\
\hline NICU stay(days) & $4 \pm 0.95$ & & 3 & & 0.710 \\
\hline
\end{tabular}

Neonatal outcome was observed for birth weight, APGAR score, admission to NICU and NICU stay as shown in table 5. Mean birth weight was $2.69 \pm 0.398$ in group A while for Group B it was $2.63 \pm 0.412$ and were comparable and statistically insignificant $(\mathrm{p}=0.662)$. APGAR score was noted at 1 and 5 minutes and were comparable for both the groups and none of the neonate had APGAR $<7$ at minutes.

Table 6: Intrapartum and postpartum morbidity.

\begin{tabular}{|llllll|}
\hline Complication & $\begin{array}{l}\text { Group A } \\
\text { (expectant } \\
\text { group) }\end{array}$ & $\begin{array}{l}\text { Group B } \\
\text { (early } \\
\text { induction) }\end{array}$ & P value \\
\hline $\begin{array}{l}\text { Clinical } \\
\text { chorioamnionitis }\end{array}$ & 0 & 0 & 0 & 0 & \\
\hline Postpartum fever & 1 & 2 & 1 & 2 & 1 \\
\hline Wound sepsis & 1 & 2 & 0 & 0 & \\
\hline Tachy systole & 0 & 0 & 0 & 0 & \\
\hline Hyper stimulation & 0 & 0 & 0 & 0 & \\
\hline PPH & 3 & 6 & 2 & 4 & 0.642 \\
\hline Total & 5 & 10 & 3 & 6 & 0.453 \\
\hline
\end{tabular}

Neonates were followed for sepsis $22 \%$ in group A and $16 \%$ in group B had neonatal sepsis, $42 \%$ in group A and $30 \%$ in group B were in need of Antibiotics and it was given to all those neonates with sepsis and who delivered after 24 hours of ROM as per the hospital protocol. Neonatal Jaundice, NICU admission and NICU stay were comparable in both the groups.

Maternal morbidity was observed in $10 \%$ women in group A and $6 \%$ in group B and was statistically insignificant as shown in Table 6 . None of the patient develop clinical Chorioamnionitis in any group.

Hospital stay was assessed for both the groups as shown Mean duration was $2.94 \pm 1.23$ for group A and $2.14 \pm 1.18$ for group $B$ and the difference was found to be statistically significant $(\mathrm{p}=0.013)$.

\section{DISCUSSION}

Prelabour rupture membranes is not uncommon but the management is controversial. PROM at term is either managed by expectant method or by induction of labour. PROM is a common indication of induction of labour. ${ }^{7}$ Early induction reduces the latency period in PROM. Oxytocin and prostaglandins are the agents most commonly used for this purpose and their success depends upon the status of cervix at the start of the induction of labour. Induction of labour with prostaglandins offers the advantage of promoting both 
cervical ripening and myometrial contraction. ${ }^{8,9}$ Studies have shown the management of patients presenting as PROM should be actively managed as prolonged PROM to delivery interval is associated with increased incidence of histologic chorioamnionitis and fetal sepsis that lead to increase fetomaternal morbidity. ${ }^{3}$ Several investigator compared immediate induction with PGE2 and delayed induction with oxytocin or PGE2 in women with term PROM. ${ }^{10}$ The present study compared the early induction by intracervical PGE2 gel to expectant management up to 24 hours followed by induction of labour if labour doesn't establish in PROM in singleton pregnancy with cephalic presentation at term (37 to 41 week) gestation.

The demographic profile of women including their age, parity, boking status, were studied and were comparable in both groups. The mean age in present study was $23.94 \pm 2.90$ years in group A and $24.34 \pm 3.07$ in Group B. It is similar to the studies of Chaudhary et al11 (23.2 \pm 4.7 vs $23.2 \pm 3.9)$ and differ from that of Larranga -Azcarate et al5 (31.5 vs31.3). In present study most of the females were nulliparous than parous women with mean gestational age $38.68 \pm 1.34$ in group $\mathrm{A}$ and $38.62 \pm 1.58$ in group B as compared to study done by Chaudhary et al, Larranga-Azcarate et al, and Bangel et al. ${ }^{5,11,12}$

The mean duration of ruptured membranes at time of admission in present study was $5.64 \pm 0.846$ in group $\mathrm{A}$ and $5.03 \pm 1.539$ in group B and it differs from the study done by Krupa et al $(3.1 \pm 2.3$ vs $2.9 \pm 2.2)$ and Kodkany et al13 (3.2 vs 2.94). ${ }^{10}$ In present study induction was done after 6 hours while others have done immediate induction. ${ }^{11}$ In the present study $100 \%$ women had Bishop Score $<6$ in both groups.

A study done by Aryal S. et al.14 also had pre-induction bishop score $<6$ and comparable. ${ }^{14}$ Rupture of membrane to active labour interval was $19.18 \pm 10.465$ vs $9.87 \pm 6.341$ for study groups and difference was found to be significant $(\mathrm{p}<0.001)$ this is comparable to study done by Krupa et al10 (15.8 \pm 9.9 vs 9.4 $\pm 5.1, \mathrm{p}<0.01)$.

Eighty eight percent women went into active labour spontaneously within 24 hours of ROM in expectant group and this is closely similar to study done by Vaishnav et al (80\%). ${ }^{15}$ Single dose PGE2 gel application was required in $8 \%$ of women and 2 nd gel required in $4 \%$ cases of group A in present study while group B 58\% had single gel and $42 \%$ had 2nd gel application this is not in agreement with the study done by Poornima et al in which $94 \%$ cases required single dose gel and $6 \%$ repeat gel application, oxytocin augmentation also differs in the similar study ( $86 \%$ vs $56 \%$ ) while it was in present study (36\% vs $32 \%$ ) in group A and group B respectively. ${ }^{16}$

Mean duration of ruptured membrane to delivery interval in present study was $(23.234 \pm 6.804$ vs $17.212 \pm 5.388$, p< $0.001)$ this is comparable to study done by Chaudhary et al $(21.63 \pm 10.3 \mathrm{vs} 17.10 \pm 10.3, \mathrm{p}<0.001) .{ }^{5}$ In present study $38 \%$ patient from group A and $86 \%$ from group B delivered within 24 hours $(\mathrm{p}<0.001)$ it is similar to study done by Krupa et al. ${ }^{10}$ In the present study, induction to delivery interval was $(10.825 \pm 2.232$ hours vs $12.912 \pm 5.388$ hours, $\mathrm{p}<0.001)$, which is similar to Poornima et al16 (7.8 \pm 1.7 hours vs $12.912 \pm 5.388$ hours, $\mathrm{p}<0.001)$ and contrary to that of Chaudhary et al $(8.52 \mathrm{vs}$ 9.59 hours). ${ }^{11}$

Ninety percent from group A and $84 \%$ from group B had vaginal delivery and there was no instrumental delivery which is in agreement to the study done by Bangal et al in which only $2 \%$ cases had instrumental delivery. ${ }^{12}$ Women delivered by caesarean section were higher in induction group in present study i.e. $16 \%$ in induction group vs $2 \%$ in expectant group $(\mathrm{p}=0.038)$ and comparable to studies done by Poornima et al and Bangal et al, $26 \%$ vs $10 \%$ $\mathrm{p}=0.12)$ and $(20 \%$ vs $14 \% \mathrm{p}=0.189)$ respectively. ${ }^{16}$ Maternal intrapartum and postpartum complications were also comparable for present study to Poornima et al16 and Bangal et al study. ${ }^{12}$ Neonatal outcome was observed for birth weight, neonatal sepsis, need of antibiotics, and neonatal jaundice, in present study mean birth weight was $2.69 \pm 0.398 \mathrm{Kg}$ and $2.63 \pm 0.412 \mathrm{Kg}$ in both study group and comparable to study done by Rawat $\mathrm{R}$ et al17 where birth weight ranges from 2.6 to 3.5 for both groups.

In present study higher number of babies had APGAR $<7$ at $1 \mathrm{~min}$ in group A than group B (44\% vs $34 \%)$ but this does not exist at 5 minutes $(56 \%$ vs $66 \%, \mathrm{p}=1.000)$ and similar to study done by Rawat et al $(\mathrm{p}=1.000) .{ }^{17}$ Neonatal sepsis was higher in expectant group than induction group which is not statistically significant in present study groups $(\mathrm{p}=0.264)$ and shows similarity to study done by Chaudhary et al5 (3.5\% vs $2.7 \%$ ). Neonatal jaundice needs of antibiotics, and NICU stay was similar to study done by Bangal et al. ${ }^{12}$

In present study primary outcome measures in term of ROM to delivery was significantly shorter in induction group, caesarean section rate significantly higher in induction group and maternal and neonatal morbidity was similar in both the groups.

Secondary outcome in terms of dose of PGE2 is significantly less in expectant group and oxytocin augmentation requirement is not significantly increased in expectant group. Hospital stay was significantly more in expectant group as compared to early induction group.

\section{CONCLUSION}

Both the options of management of PROM has their own advantages and disadvantages. Early induction led to significant reduction in ROM to active labour and delivery interval and lesser duration of hospital stay but rate of caesarean delivery and fetal distress increased significantly. On other side expectant management for 24 hours did not lead to significant risk of maternal and neonatal infection per se and resulted in reduction of caesarean delivery and fetal distress but need of 
antibiotics to neonates, ROM to delivery interval and hospital stay increased significantly. Therefore, expectant management up to 24 hours followed by delayed induction with PGE2 gel can be safely offered to a woman with term PROM. So, women with term PROM can be given informed choice between the two management options -expectant management for 24 hours and early induction explaining the merits and demerits of both the options.

\section{ACKNOWLEDGMENTS}

Author would like to acknowledge to all clinical and para clinical staff who have well maintained the files and take care of the patients who participated in the study to accomplish this Prospective analysis and all those authors whose study included for comparison analysis.

\section{Funding: No funding sources}

Conflict of interest: None declared

Ethical approval: The study was approved by the Institutional Ethics Committee

\section{REFERENCES}

1. Gunn GC, Mishell DR Jr, Morton DG: Premature rupture of fetal membrane at term. A review: Am J Obstet Gynecol. 1970;106(3):469-83.

2. Dare MR, Middleton P, Crowther CA, Flenady VJ, Varatharaju B. Planned earl birth versus expectant management (waiting) for Prelabour rupture of membrane at term (37 week or more). Cochrane Database of syst Rev. 2006; 1:CD005302.

3. Duff P. Premature rupture of the membranes in term patients. Semin Perinatol. 1996;20(5):401-8.

4. Reece EA, Chervenak FA, Moya FR, et al: Amniotic fluid arborization: Effect of blood, meconium, and $\mathrm{pH}$ alterations. Obstet Gynecol. 1984;64(2):248.

5. Larranaga-Azcarate C, Campo-Molina G, PerezRodri'guez AF, Ezcurdia-Gurpegui M. Dinoprostone vaginal slow release system compared to expectant management in the active treatment of premature rupture of the membranes at term: impact on maternal and fetal outcome. Acta Obstetrica. 2008; 87(2):195200.

6. Parson M, Spellacy W. Premature Rupture of membranes, Danforth's Obstetrics and Gynaecology, editor James R. Scott et al; Lippincott Williams and Wilkins, 8th Edition:1999;269-76.
7. Induction of labour - NICE clinical guideline 70 - NHS Choices Available at https://www.nhs.uk/planners/pregnancycareplanner/.../n ice_induction_of_labour.pdf

8. Idem. Prostaglandins for prelabour rupture of the membranes at 34 + weeks. In: Enkin M, Keirse MJNC, Renfrew MJ, Neilson JP, eds. Chochrane pregnancy and childbirth database. Oxford, England: Cochrane, 1993. (Review no. 07154.) (Software.)

9. Song J. Use of misoprostol in obstetrics and gynecology. Obstet Gynecol survey. 2000;55(8):50310.

10. Krupa S, Doshi H. Premature Rupture of Membrane at Term: Early Induction Versus Expectant Management; J Obstet Gynaecol India. 2012; 62(2):172-5.

11. Chaudhary S, Mitra SN, Biswas PK, Bhattacharyya S: Premature Rupture of membranes at term: immediate induction with PGE2 Gel compared with Delayed induction with oxytocin: J Obstet Gynaecol India. 2006;56(3):224-9.

12. Bangal VB, Gulati P, Shinde KK, Borawake SK: Induction of labour versus expectant management for premature rupture of membranes at term: IJBR 2012;3(3):164-70.

13. Kodkany BS, Telanga MA: Premature rupture of membranes: A study of 100 cases: J Obstet Gynaecol India 1991:41(4):492-6.

14. Aryal S, Karki C. Induction of Labour in Prelabour Rupture of Membranes with or without Cervical Ripening with Prostaglandin E2: J Lumbini Med College. 2014;2(1):4-9.

15. Vaishnav J, Vaishnav G. A study of feto-maternal outcome in patients with pre-labour rupture of membranes at term (>37 weeks). Med Sci. 2011;1(2):118-24.

16. Poornima B, Reddy DD. Premature rupture of membranes at term: immediate induction with PGE 2 gel compared with delayed induction with oxytocin. J Obstet Gynecol India. 2011 Oct 1;61(5):516-8.

17. Rawat R, Divedi P, Debbarma S, Vishwakarma S, Mittal N. A comparative study between active and expectant management of premature rupture of membranes at term on fetomaternal and perinatal outcome in rural population: Int $\mathrm{J}$ Reprod Contracept Obstet Gynecol. 2018;7(6):2393-8.

Cite this article as: Gupta A, Gautam S, Prakash O, Chauhan M. Early induction versus expectant management in prelabour rupture of membranes. Int J Reprod Contracept Obstet Gynecol 2018;7:4634-9. 